\title{
Transformation of a Lawyer into Successful Dairy Entrepreneur: A Success Story
}

\author{
Maina Kumari $^{1^{*}}$, Amit Kumar ${ }^{2}$ and Kamlesh Kumar Dhawal ${ }^{3}$ \\ ${ }^{1}$ Department of Veterinary and Animal Husbandry Extension Education, \\ Apollo College of Veterinary Medicine, Jaipur (Rajasthan), India \\ ${ }^{2}$ Department of Veterinary Gynaecology and Obstetrics, \\ Post-Graduate Institute of Veterinary Education \& Research, Jaipur (Rajasthan), India \\ ${ }^{3}$ Animal Husbandry Department, Rajasthan, India \\ *Corresponding author
}

\section{A B S T R A C T}

\begin{tabular}{|l|}
\hline Ke y w or d $\mathbf{s}$ \\
Entrepreneurship, \\
Dairy farm, \\
Machine milking, \\
Vermicompost, \\
Eco-tourism. \\
\hline Article Info \\
\hline $\begin{array}{l}\text { Accepted: } \\
\text { 15 May } 2020 \\
\text { Available Online: } \\
\text { 10 June } 2020\end{array}$ \\
\hline
\end{tabular}

In India, most of the dairy production centres have been managing through cooperative, private bodies or by individuals. This story is specifically articulated successful management of a cattle dairy named "Cowbell Dairy Farm" located at Beechwal area of Bikaner district in Rajasthan state (India). An entrepreneur named Mr. Naveen Tanwar who is a lawyer by profession, established a dairy aimed to provide clean, hygienic and organic milk to the people. He started the dairy in year 2012 with fifteen cows after collecting adequate knowledge about animal husbandry from RAJUVAS, IABM, existing dairy farmers and from various sources. Now a day, he is rearing approx. 200 cattle and having milk production of 1200 lit/day which is consumed by over 700 families of Bikaner. This dairy farm is facilitated with machine milking, artificial insemination, milk testing lab, and residence for workers and also equipped with the different latest equipment of animal managemental practices like CCTV surveillance, solar lights, foggers, electronic groomers etc. With the availability of sufficient land and natural habitat, he has well established the eco-tourism centre for commercial purposes and adopted different agricultural practices like integrated farming, cultivation of fodder crops, vermicompost, farming of medicinal and fruit plants. This dairy entrepreneur is earning Rs. 15-20 lakhs per annum and has employed 12-15 persons. So, it can be said that "Cowbell Dairy Farm" of Mr. Naveen Tanwar is the successful model for the dairy entrepreneurship.

\section{Introduction}

Entrepreneurship is perceived as primarily innovation and concept which is not only vital for starting industries but also in the development of agriculture, whereas to other scientists, it comprehends as market stabilizing force, owning and managing a small venture (Nandapurkar, 1982; Joshi et al., 2017). The economic development of a country is directly related to the entrepreneurship development (Madhushree and Sunayana, 2018). An entrepreneur is a person who creates something new, undertakes risk; eliminates disequilibrium between aggregate supply and aggregate demand by exploiting market opportunities or as one who owns and operates a venture 
(Tyson et al., 1994). An entrepreneur not only establishes himself as a successful businessman but also creates job opportunities directly and indirectly for others and also sets a live example for new entrepreneurs for adopting the livestock farming as a successful business model. They also play a key role in promoting economic growth and technological changes in the country.

In India, about $70 \%$ of the population depend on agriculture and allied sectors for their livelihood. Animal husbandry has been practised as a subsidiary occupation to agriculture. Livestock rearing is generally practised by the small and marginal farmers having a land holding of $1 / 2$ to 2 acres maintaining 2 to 3 animals.

Livestock sector not only gives subsidiary income to the farmers, but also helps in employment generation as well as providing nutritional security in the form of milk, meat and egg. Over $70 \%$ of the rural households in India own livestock and a majority of livestock owning households are small, marginal and landless households (Verma, 2018). Besides providing organic manure, livestock is an important source of several value-added by-products, which are not properly, processed and utilized as a commercial activity, but have immense future business potential.

Dairy farming is a crucial component of a rural economy that has the highest potential of generating income and employment through augmenting the productivity of milch animals. It is one of the promising sectors for entrepreneurship development in India (Lazar, 2014). As far as the dairy entrepreneurship is concerned, development of the dairy through the application of modern science and technology will greatly contribute to improving the socio-economic conditions of rural masses by making dairy farming more productive and remunerative (Dakhore et al., 2002). A dairy entrepreneur is a person who is responsible for various activities involved in dairy farm management. The dairy entrepreneur should work independently and have the ability to make various strategic and operational decisions about his area of work.

The individual should have clarity, resultoriented and skilled to use various tools. Behavioural characteristics like innovativeness, risk-taking capacity, achievement motivation, self-confidence, planning ability, cosmo-politeness, coordinating ability are some of the characteristics of a successful farmer (Chandraker et al., 2019).

Such a 36-year-old dairy entrepreneur named Naveen Tanwar is successfully running a modern dairy "Cowbell Dairy Farm" which is situated $14 \mathrm{~km}$ away from Bikaner city in Rajasthan state (India). So, this case study will motivate all the needy ones who are planning to establish a livestock enterprise with a small amount of budget. This success story will help various unemployed youth, farmers and entrepreneurs to understand and study every aspect of dairy farming so that they can be prepared very well with skills, determination, pros and cons before starting their own business.

\section{History}

\section{Idea generation: "News of adulterated milk"}

Mr. Naveen has the habit of reading newspapers daily. One day he read about an article on adulterated milk in a magazine. He decided to test the milk which was being supplied and consumed at his home. He found it adulterated and of poor quality. So, he decided to keep two crossbred cattle at his home to get quality and hygienic milk. 
He started supplying milk to his friends and relatives. He got very good responses from them and day by day demand of this milk were increased. He realized that he would want to do something for the society too and that was the point where idea of social entrepreneurship seeded. The only concept in his mind at that time was "provide hygienic milk" all over the city. So, he left his job as lawyer to establish a dairy farm on large scale at his farmhouse.

\section{Collection of information}

He followed step by step procedures and worked out in a much planned manner. He started visits to modern dairies and collected information about setup, investment, labour management, losses and benefits, etc. After that, he thought about available resources he had and prepared a dairy infrastructure. He also got information and support from social media, Institute of Agriculture Business Management (IABM) and Rajasthan University of Veterinary and Animal Sciences (RAJUVAS), Bikaner.

\section{Training}

The entrepreneur put all his efforts into making his business a successful one, after the collection of information from all the resources. He consulted with the gynaecological experts of Rajasthan University of Veterinary and Animal Science, Bikaner and worked under the guidance of them. He collected information about various diseases of animals, management practices, various medicines and vaccines to be used in their area and about milk i.e. fat and SNF percent, etc.

\section{Procurement of resources}

He started the dairy on his parental land (10 hectares) with fifteen crossbred cattle by spending money Rs. 7.50 lakhs (Rs. 50,000/cattle) and Rs. 2.5 lakhs for animals and sheds, respectively. He hired two labourers (Rs. 8,000/ labourer/ month) and provided training by himself on the basis of what he has learnt earlier and provided accommodation to them and their families. Facilities like electricity, water and cooking gas were also provided to them. For breeding, artificial insemination was started by help of gynaecological experts of RAJUVAS. He established milking machine and some managemental tools for animals.

\section{Present status of dairy farm}

At present, "Cowbell dairy farm" is a fastgrowing and recognised model of Bikaner area which is well equipped with the latest technologies of production and managemental practices. Now a day, he has approx. 200 cattle (70 lactating, 30 dry, 40 heifers and 55 young ones) at his farm. The total milk production of his dairy farm is average about 1200 litres/day which is being sold at Bikaner city by the auto vehicle without any middle man. The milk production of this dairy farm is increasing by $20-25 \%$ per year due to better managemental practices.

There is a facility of both close and loose management systems separately. The farm also has a separate management system for milking, dry, heifers and young animals. He provides open "natural habitat" to the animal by growing plants and has facility of electric fogger and fan during summer to mitigate heat stress. He has been earning about Rs. 1215 lakh per annum and has given employment to 10-15 persons on contract basis for farm management and supply of the milk. At present about 700 families of Bikaner district are consuming the milk from this farm. The dairy farm has been visited by farmers, veterinarians and entrepreneurs for motivating themselves. 


\section{Unique practices}

\section{Untouched milk}

Milking is being done by imported and branded machines. He has developed the procedure of untouched milk from collection to supply or consumption.

\section{Milking parlour}

He has constricted a milk parlour as separate milking pen having capacity of fourteen animals to produced clean and hygienic milk.

\section{Natural habitat}

There is an open paddock with plantation to provide a natural and comfortable environment for the animal. He keeps animals loose after milking.

\section{Use of ARTs for breeding}

$\mathrm{He}$ has been adopting the assisted reproductive techniques (ARTs) like artificial insemination and oestrus synchronization. $\mathrm{He}$ imports the semen from NDDB (National Dairy Development Board) \& ABS (?) for breeding his animals by artificial insemination method. In This Farm CCTV surveillance and teasure bull are tools for heat detection.

\section{Ecotourism centre}

Due availability of sufficient land and natural habitat, he has well established the ecotourism centre for commercial purposes. $\mathrm{He}$ manages the different expenses of his farm by the income from this centre.

\section{Record keeping}

Records of milking, accounts and other managemental practices are being managed by android software.

\section{Safety and security}

The whole farm is under CCTV surveillance. He has kept some dogs for security of animals when they remain in loose paddock.

\section{Evaluation of animals}

Routine tests of milk for subclinical mastitis are being performed at his farm. He also examines his animals to find out any deficiency or diseases.

\section{Temperature control}

The shed is facilitated by cooler, fans and fogger systems. He has also grown green plants on 1.75 hectares of land to control temperature during the summer period to prevent heatstroke/heat stress.

\section{Mastitis control}

The incidence of mastitis is very low at his farm due to maintaining hygienic milking and adopting dry cow therapy. There is a routine practicing of washing and dipping of teats and udder by the solutions just before and after milking.

\section{Health care}

He regularly practices the deworming and vaccination of animals. Treatment of diseased animals is being done only by an experienced veterinary doctor.

\section{Challenges faced}

\section{Labour issue}

Hiring skilled and cheaper labour had been a very difficult task due to the tendency of quitting the job by unskilled labour. 


\section{Housing management}

Bikaner area is included in arid region so management of heat stress and availability of green fodder is always challenging. High humidity makes it more difficult.

\section{Marketing \& pricing of milk}

This farm is situated $14 \mathrm{~km}$ away from Bikaner city therefore, it is very difficult to manage a cheaper labourer, transportation costs and maintain cold chain. Getting the right price and marketing of the milk is very tough because the people are not ready to afford the pricing of milk.

\section{Health}

Sometimes, it becomes very difficult to treat the cases of repeat breeding.

\section{Lack of manager}

He observes and manages this farm himself because he usually says that "the owner is the best manager". If you hire the wrong manager, then they bring endless issues. So many times, it becomes very difficult to manage the farm in absence of him.

\section{Future planning}

\section{Establishment of biogas plant}

$\mathrm{He}$ has sufficient number of animals for establishing the biogas plant to utilize the energy in many works which will be conducted at his farm.

\section{Increase the spectrum of integrated farming system (IFS)}

$\mathrm{He}$ is earning the income by selling the fruits and medicinal plants also. Now, he is planning to increase its spectrum by adopting apiculture, horticulture etc.

\section{Constitute a dairy cooperation}

He wants to create a group of successful dairy entrepreneurs, so that all entrepreneurs can get right pricing of their hygienic milk by loud their voice against milk adulterating cliques.

\section{Organic farming}

Now, he is planning to replace the existing farming by organic purely. So, for this purpose, he is developing his own organic resources for the production of crops, fertilizers and even treatment by ethnoveterinary practices.

\section{Initiatives}

\section{Medicinal plants}

He has grown some medicinal plants viz. Ashwagandha, Ambla, Sajan, etc, at the farm. These plants are rich in vitamins, minerals and essential amino acids so they not only enhance the health of the animal but also raising the nutritive value of milk.

\section{Vermicomposting}

Vermicompost is also producing at this farm with the cow dung and urine. There is a huge demand for vermicompost throughout the city for organic farming as this is illustrating trend in the recent era. He utilizes the maximum amount of vermicompost at his farm for nourishing the plants, vegetables as fertilizer and sells the remaining to nearby small farmers.

\section{Eco-tourism centre}

The farm is producing almost organic fodder and milk. It is the land of agri-eco-tourism with high standard quality regarding organic integrity, environmental-friendly practices 
and sustainable dairying and farming. The farm is being visited by local people, dignitaries, students and new dairy entrepreneurs.

\section{Achievements}

\section{Active social participation}

He was invited in a brainstorming session on "technological innovation and strategies for prosperity of farmers in Rajasthan" and represented the Bikaner district. He has also participated in many seminars, workshops, and symposiums at the national level.

\section{Acknowledge}

Feeding of medicinal plants as an extent makes the milk as like Amrit. His initiative was acknowledged by PASHU AYURVEDA.

\section{Telecast}

Cowbell's scientific farming was telecasted in Aandata series at DD national and Krishi Darshan television.

\section{Publicity}

Cowbell farm has been visited by various dairy farmers of the country, veterinarians, college students, dignitaries, children's and army officers to see the liveability of this farm. This study revealed that the development of the selected innovations was mostly in response to a 'problem' faced by particular farmers. This investigation is a maiden attempt to study the successful transformation of a lawyer into a dairy entrepreneur. Mr. Tanwar's 'Cowbell Dairy Farm' is the best example of a successful dairy entrepreneurship model. Hence, the model can be used in other parts of the country to establish a dairy farm and cooperatives. According to Mr. Tanwar, the profit gained per day through the sale of milk was comparatively more than rural farmers. In his dairy, he maintained improved breed, more herd size, adopted scientific management practices by receiving services and inputs from the cooperative, Veterinary University and other institutes which enabled him to gain more milk yield and thus more profit.

This success story can say that the dairy entrepreneurship enabled him to meet the financial crises confidently through dairy farming which empowers him socially and economically. The major reason for the establishment of the Cowbell Dairy Farm was providing hygienic, quality and pure milk with an affordable price to the consumers by the producing it in a better environment and also for eliminating middleman through direct sale of milk to consumers.

The deciding factors of the strength of Cowbell Dairy Farm are branding, ecofriendly products and the adoption of the latest techniques. The government should develop programmes specifically targeted to dairy farmers to enhance entrepreneurship in dairy farming practices. The successful case study of farmers as well as companies should be documented and published for the motivation and interest of other farmers. This Cowbell Dairy farm is not just producing the milk only, but it has established itself as vibrant dairy industry that ensures an alternate source of income to the farmers and it leads to an all-round self-sustaining socioeconomic development at the individual as well as community level.

\section{References}

Chandraker, K., Pandey, A.K., Oraon, J., Sinha, G.R., and Yadav, A. 2019. Case study of an entrepreneur involved in livestock farming. The Pharma 
Innovation Journal. 8(12):181-184.

Dakhore, K.M., Deshmukh, K.A., and Ingole, P.G. 2002. Training needs of dairy owners as entrepreneur. Maharashtra Journal of Extension Education. 21(2):71-73.

Joshi, P., Tiwari, R., and Sathisha, M.C. 2017. Case study of an entrepreneur involved in dairy business. Agricultural Rural Development. 4:17-20.

Lazar, N., 2014. Role of women entrepreneurs in dairy sector with special; reference to Thrissur district of Kerala. Indian J. Appl. Res. 4(11): 296298.

Madhushree, H.G.,and Sunayana N. 2018. A comparative analysis on behaviour of trained and untrained entrepreneurs - a study on dairy industry. International Journal of Mechanical Engineering and Technology. 9(1): 1005-1009.

Nandapurkar, G.G., 1982. Small farmers-A study on their entrepreneurial behaviour. Metropolitan Book Co. (Pvt. Ltd.), New Delhi. pp. 1-2.

Tyson, L., Petrin, T. and Rogers, H. 1994. Promoting entrepreneurship in central and Eastern Europe. Small Business Economics. 6: 1-20.

Verma, A., 2018. Importance and Scope of Animal Husbandry in Watershed. Livestock Management. A publication of Indira Gandhi National Open University, Delhi. pp. 5-29.

\section{How to cite this article:}

Maina Kumari, Amit Kumar and Kamlesh Kumar Dhawal. 2020. Transformation of a Lawyer into Successful Dairy Entrepreneur: A Success Story. Int.J.Curr.Microbiol.App.Sci. 9(06): 431437. doi: https://doi.org/10.20546/ijcmas.2020.906.057 